\author{
Dejan Bodul, PhD, Assistant Professor \\ University of Rijeka, Faculty of Law \\ Hahlić 6, 51 000, Rijeka, Croatia \\ dbodul@pravri.hr
}

\title{
THE RIGHT TO A HOME IN THE CASE-LAW OF ECHR VS. THE RIGHT TO A HOME IN THE CASE- LAW OF CROATIAN COURTS ${ }^{1}$
}

\begin{abstract}
The legal concept of the "right to a home" reflects the principle of social solidarity. It is rooted in modern philosophical and theoretical humanistic school of thought, but also in the secular sense of avoiding social Darwinism. Nevertheless, this principle can, as any other, turn into its own opposite. Its realisation can also result in consequences that challenge its meaning. However, this does not diminish its value. The emphasis here is on the modalities of its application. Therefore, the author shall analyse the practice of the European Court of Human Rights (hereinafter: ECHR) in proceedings concerning the right to a home and its implementation in the Croatian legal system. He assumes that these findings could be a key to understanding the subject of the paper based on ECHR case-law. The complexity of the research topics and the set tasks of this paper determined the choice of methods. Consequently, the author used normative legal methodological approach in the analysis. It is important to note that the scope of this paper does not allow for a detailed analysis of this topic; we are therefore forced to limit our analysis exclusively to some aspects/issues of the new enforcement legislation.
\end{abstract}

Keywords: the right to a home, case-law of the ECHR, case-law of domestic courts

\section{DISCUSSION FRAMEWORK}

Doctrinal discussions as well as the experience of Croatian courts indicate that the issue of "the right to a home" is a sensitive subject for a number of economic, social, and political and legal reasons. The case-law of the ECHR also provides a new dimension to this problem. Namely, acknowledging the fact that the ECHR and its concept of the right to a home affirms the precedent principle and thus jurisprudence as a formal source of law, the question is whether our case-law can transform itself from the practice of "positivism" into the practice of "creativism and court activism"?

This paper is supported byt he Croatian Science Foundation under Project 6558, Business and Personal Insolvency - the Ways to Overcome Excessive Indebtedness 


\subsection{THE RIGHT TO A HOME IN THE NORMS AND PRACTICES OF THE ECHR}

The author believes that Croatian reforms, primarily those of enforcement law, have created a conceptual confusion about the legal nature and the function of the concept "the right to a home". The reason is primarily the fact that the right to a home as a constitutional and convention right ${ }^{2}$ and as a civil legal basis for the use of a home, the right of ownership, may appear in certain situations as contradictory rights in court proceedings. Namely, in civil proceedings in which the owner, non-possessor, (or the supposed owner-non-possessor) demands from the ownerpossessor to surrender a particular real-estate and the possessor objects referring to the right to a home, the question can be raised before a civil court (or enforcement court in an enforcement procedure) which of these rights has advantage, but also according to which criteria. ${ }^{3}$ Therefore, it seems that the key to overcome this potential problem is in the analysis of ECHR jurisprudence.

\subsubsection{The concept of home within the meaning of Article 8 of the European Convention for the Protection of Human Rights and Fundamental Freedoms (hereinafter: ECHR)}

The concept of home is an autonomous term within the meaning of Article 8, paragraph 1 of the ECHR. The French version of the ECHR text uses the term domincile that has a much wider meaning than the English term home. According to the practice of the European Court of Human Rights (hereinafter: ECHR), home is considered a physically defined area where private and family life develop. ${ }^{4}$ In the case Oluic $v$ Croatia $^{5}$, the ECHR referred to the very broad scope of the term:

"Article 8 of the Convention primarily protects the individual's right to respect for his private and family life, his home and his correspondence. A home will usually be a place, a physically defined area, where private and family life develop. The individual has the right to respect for his home, meaning not just the right to the actual physical area, but also to quiet enjoyment of that area. Violations of the right to respect of the home are not confined to actual or physical violations, such

2 European Convention on Human Rights, OG-IT, no. 18/97, 6/99, 14/02, 13/03, 9/05, 1/06 and 2/10, hereinafter: European Convention

3 Kontrec, D., Pravo na dom u praksi Europskog suda i domaćih sudova, Pravo u gospodarstvu, Zagreb, vol. 56, 2017, no. 5, p. 1061-1099

4 Harris, D. J., O’Boyle, M., Warbrick, C., Law of the European Convention on Human Rights, Oxford, Oxford University Press, 2009, p. 376

$5 \quad$ Oluić v Croatia, judgment, 20/05/2010, no. 61260/08 
as unauthorised entry into a person's home, but also those that are not concrete or physical, such as noise, emissions, smells or other forms of interference. A serious violation may result in the breach of a person's right to respect their home if it prevents them from enjoying the amenities of their home...". Therefore, the assessment of whether a certain area of residence is covered by Article 8 (1) depends on factual circumstances, particularly the existence of permanent and sufficient links to that area. For example, in the judgment of Paulic $v$ Croatia, ${ }^{6}$ the ECHR ruled: "The term home is an autonomous notion that does not depend on classification within domestic law. Whether certain premises are to be defined as a home, which is protected under Article 8, paragraph 1, depends on factual circumstances, such as the existence of permanent and sufficient links to a particular area. ${ }^{7}$ Accordingly, whether property qualifies as a home is a matter of fact and does not depend on the legality of use within domestic law". As with most other substantive convention rights, when it comes to the right to a home, the ECHR conducts the so-called "test of applicability" to determine whether the facts of a particular case fall within the scope of Article 8. As evident from the Paulić judgment, there is a requirement for sufficient and permanent links with a certain area or property, which must always be specific and persistent. ${ }^{8}$

\subsubsection{Interfering into the right to a bome}

With respect to the right to a home, Article 8, paragraph 1 gives the right to: access the home, home use, and its peaceful enjoyment. However, the rights guaranteed by Article 8 fall into the category of rights that may be restricted. All the rights that can be restricted function in the same manner. The right is guaranteed in the first paragraph of the article. If there is interference into the rights under the first paragraph, that interference can be justified by invoking the second paragraph. If the criteria set out in the second paragraph are fulfilled, interfering will be granted by the law. Therefore, restrictions or interference in the right will be legitimate.

The burden of proof that there has been interference with someone's rights is on the person claiming that there has been a violation of Article 8. The burden of

Paulić v Croatia, judgment, 22/10/2010, no. 3572/06

7 See, Gillow v United Kingdom, judgment, 24/11/1986, no. 9063/80; Buckley v United Kingdom, judgment, 25/09/1996, no. 20348/92, Wiggins v United Kingdom, decision, 08/02/1978, no. 7456/76, Prkopovich v Russia, judgment, 18/11/2004, no. 58255/00 and McCann v United Kingdom, judgment, 13/05/2008, no. 19009/04

$8 \quad$ Omejec, J., Konvencija za zaštitu ljudskih prava i temeljnih sloboda u praksi Europskog suda za ljudska prava, strasburški acquis, Novi informator, Zagreb, 2013, p. 936 
proof is then transferred and must be justified by those who have participated in the interference. ${ }^{?}$

The ECHR has made it clear that it always applies a similar methodological approach when examining whether there has been any interference with the rights protected by Article 8 . It is a judicial review technique called "step by step". Taking into consideration the broad scope of free assessment in the application of Article 8 , paragraph 1 , the main part of this examination will always include the issue of justification of disputed interference in a protected right in the centre of which is the conduct of a test of "necessity in a democratic society". "Necessity" implies an "urgent social need" and a comprehensive analysis of that test requires its reading in terms of general features of the principle of proportionality and necessity. ${ }^{10}$

The stages of determining whether there has been a violation of Article 8 are the following:

1. Is the area in question home within the meaning of Article 8? The applicant is required to state the right in question.

2. Has there been any interference from state or public authorities in exercising the applicant's right to his home? The applicant must prove that there had been an interference.

3. Was the interference justified? In order to determine whether the interference was justified under Article 8 (2), the ECHR must examine whether it was in accordance with the law, whether it had a legitimate aim under that paragraph and whether it was necessary in a democratic society for achieving the foregoing goal. ${ }^{11}$

a) Was the interference in accordance with the law? The burden of proving the legality of interference is on the state.

b) Is there a legitimate goal? Article 8, paragraph 2 allows for interference based on one or more of the following grounds: national security, public security or economic benefit of the country, in order to prevent riots or crimes, in order to protect the rights and freedoms of others. These are the legitimate goals which the article and the ECHR accept as a justification for interfering. The state must identify justification for interfering.

Interights, Pravo na poštovanje privatnog i obiteljskog života, doma i dopisivanja, Priručnik za izobrazbu odvjetnika/ica, p. 13-14

10 Omejec, op. cit. note 8, p. 950

11 Exempli causa, Blečić v Croatia, judgment, 29/07/2004, no. 59532/00 
c) Is interference necessary in a democratic society? Based on objective considerations, is there an urgent social need to limit rights and does this urgent social need pursue a legitimate aim? Essentially, what this criterion demands is a very good reason to interfere with the right. This very good reason must be in line with democratic values. The proof of this criterion is on the state.

4. Was the imposed limitation proportional? ${ }^{12}$

\subsubsection{Is the area in question home within the meaning of Article 8?}

In the framework of this issue, the ECHR examines whether the disputed act or the act of the respondent State is challenged by the applicant under the Convention, i.e. a right protected by the European Convention. This is a preliminary examination of the compatibility of the applicant's request with the article of the European Convention to which the ratione materiae is referred. ${ }^{13}$

\subsubsection{Has there been interference from state or public authorities in exercising the applicant's right to a home?}

Article 8, paragraph 2 begins by stating "public authority will not interfere in the exercise of this right ... except ...". The ECHR always starts its considerations in relation to Article 8 by determining whether there has been any real interference of a public authority with any of the rights contained in Article 8 (1). In most cases, the answer to that question will be completely obvious. ${ }^{14}$ The respondent state usually does not even try to dispute the allegations of interference, e.g. when a person is prevented from living in their home, disabling a person's access to their home,${ }^{15}$ accessing another home for which that person is very emotionally attached ${ }^{16}$ or destroying a person's home. ${ }^{17}$

Because of its focus on individual autonomy, the rights under Article 8 are, more than any other, related to complex issues of judgment of personal and social morality. All modern states would accept absolute ban on torture, even if they in practice bypass this ban. However, when it comes to the rights guaranteed by $\mathrm{Ar}$ ticle 8 of the European Convention, there is no such unanimity. States, each in its

\footnotetext{
12 For more see, Omejec, op. cit. note 8, p. 950-951

13 Ibid., p. 1255

14 Interights, op. cit., note 9, p. 16

15 Gillow v United Kingdom, judgment, 24/11/1986, no. 9063/80

16 Demades v Turkey, judgment, 31/07/2003, no. 16219/90

17 Akdivarv Turkey, judgment, 16/09/1996, no. 21893/93
} 
own way and taking into account their cultural, ethical, religious, social, and other environment, try to impose restrictions on how people live, where they live, how they regulate their lives and how they relate to other family members. Therefore, judgments related to Article 8, i.e. personal autonomy, do not rest on formalised standards. They are always contextualised. They are often concerned with socially controversial issues and many are perceived as underminers of social cohesion. It is often pointed out that these rights are a matter of choice, so their acceptance at the national and European level usually requires subordination to the presumed will of the majority. ${ }^{18}$

The source of positive obligations of the States Parties under Article 8 derives from the normative expression "the right to respect". However, that term is not precisely defined. Thus, the ECHR has determined that in each particular case it is necessary to take into account diversity of practice in the States Parties, which is why the requirement of respect(for home, private life, etc.) differs from case to case. ${ }^{19}$ The primary obligation of the state and public authorities under Article 8 is to refrain from interfering with the right to respect for private and family life, home and correspondence of an individual. The ECHR has interpreted the right to respect as an order to the State to take positive steps to ensure the protection of the enjoyment of the rights under Art. 8, paragraph 1. In the case Marckx $v$ Belgium ${ }^{20}$ the ECHR noted that:"it is the basic purpose of an article to protect an individual against arbitrary interference from public authorities. However, not only does it oblige the state to refrain from such interference but, apart from that primary negligence, there may be positive obligations inherent in effective respect for family life." 21

Positive obligations of the states should not be interpreted as imposing an impossible or disproportionate burden on national authorities. They should not be used as a mechanism to limit the rights of others. Within these limits, positive obligations from the material aspect of Article 8 primarily require establishment of a legal framework providing effective protection of the rights protected by Article 8 . National legislation must ensure that any interference with these rights is properly regulated. In order to achieve this, the country has different means on its disposal, but a law that does not meet this requirement leads to violation of Article 8, paragraph 1 , and there is no need to examine it under Article 8, paragraph 2. ${ }^{22} \mathrm{On}$

\footnotetext{
18 Omejec, op. cit. note 8, p. 931

19 Ibid.

20 Marckx v Belgium, judgment, 13/06/1979, no. 6833/74

21 Interights, op. cit. note 9, p. 10

22 Marckx v Belgium, judgment, 13/06/1979, no. 6833/74
} 
the other hand, in certain circumstances, a positive obligation may require active taking of measures to prevent violation of the rights protected by Article 8, even when it implies regulating the relationship between individuals. In the aforementioned Oluic v Croatia case, ${ }^{23}$ the ECHR determined: "While it is essentially the goal of Article 8 to protect the individual from arbitrary interference from public authorities, it may also include (obligation) for the authorities to take measures aimed at ensuring respect for private life even in the sphere of relations between individuals. ${ }^{24}$ Irrespective of whether the case is being considered in terms of the State's positive obligation to take reasonable and appropriate measures to secure the applicant's rights under paragraph 1, Article 8 or in the sense of interference by the public authorities which should be justified in accordance with paragraph 2, the applicable principles are quite similar. In both contexts fair balance that has to be achieved between the competing interests of the individual and of the community as a whole must be taken into consideration. Furthermore, even in relation to the positive obligations arising from the first paragraph of Article 8, in achieving of the required balance, the aims mentioned in the second paragraph may be of certain relevance...". ${ }^{25}$

In addition to the positive obligations, Article 8 also imposes negative obligations on the States Parties. Thus, in the case Abdulaziz, Cabales and Balkandali v United Kingdom, ${ }^{26}$ the ECHR reminded that the objective of Article 8 was to protect an individual against arbitrary interference of public authorities. "This is a fundamental negative aspect of Article 8, i.e. the obligation of the States to refrain from any interference, detention or exploitation of the protected rights of individuals which would be contrary to Article 8 (2). ${ }^{27}$

As mentioned above, Article 8 is essential for the functioning of a democratic society, but it may legitimately interfere with these rights. Therefore, the ECHR most frequently applies the doctrine of free assessment when it decides on interfering with the rights under Article 8. This term was introduced for the first time in the case Handyside $v$ United Kingdom. ${ }^{28}$ It allows states a certain level of freedom when deciding whether a restriction is necessary, bearing in mind the circumstances in a certain country, the issue at hand, as well as its background. However, the ECHR

\footnotetext{
23 Oluić v Croatia, judgment, 20/05/2010, no. 61260/08

24 See, Stubbings and others $v$ United Kingdom, judgment, 22/10/1996, no. 22083/93, 22095/93 and Surugiu v Romania, judgment, 20/04/2004, no. 48995/99

25 Omejec, op. cit., note 8, p. 945

26 Abdulaziz, Cabales and Balkandali v United Kingdom, judgment, 28/05/1985, no. 9214/80, 9473/81, $9474 / 81$

27 Omejec, op. cit., note 8, p. 944 et seq.

28 Handyside v United Kingdom, judgment, 07/12/1976, no. 5493/72
} 
reserves the right to determine whether the State has in any case exceeded its discretionary powers. ${ }^{29}$

\subsubsection{Was the interference justified?}

\subsection{Legality}

The first obligation imposed by the human rights standards is the requirement that any interference concerning human rights must have a clear legal basis. This means that the sued State may justify its interference in the protected right referred to in Article 8 only if it is based on a law or another regulation that justifies such interference. ${ }^{30}$ In the ECHR practice, the term "law" is interpreted autonomously. Thus, all powers of authorised law-enforcers must be founded in the law. Secondary and delegated legislation is also taken into consideration while based in primary legislation. ${ }^{31}$ The concept of the law encompasses both written and customary law ${ }^{32}$ as well as judicial practice. Also, the concept also covers the law of the European Union $^{33}$ and international law ${ }^{34}$ if it meets the criteria laid down by the ECHR case-law, which, depending on a particular case, arises under that term.

In the case Sunday Times $v$ United Kingdom, ${ }^{35}$ the ECHR has set out two criteria under which certain provision is regarded as law: "First, the law must be available: the addressees must know under what circumstances the law applies. Second, the law must be sufficiently precise to enable the addressees to behave according to it". ${ }^{36}$ Therefore, there must be a legal basis for interference in national legislation, and the law must be accessible and sufficiently precise. The purpose of this requirement is to avoid the dangers of state arbitrariness. As a result of the widespread application of Article 8 and the fact that it deals with many controversial issues, it is crucial that potential interference is allowed and that it has a clear legal basis. Since Article 8 is applicable to many aspects of everyday life, the law must effectively regulate the activities of public bodies that may interfere with them.

\footnotetext{
29 Interights, op. cit., note 9, p. 11

30 Groppera Radio AG v Switzerland, judgment, 28/03/1990, no. 10890/84

31 Barthold $v$ Germany, judgment, 25/03/1985, no. 8734/79

32 Sunday Times $v$ United Kingdom, judgment, 26/04/1979, no. 6538/74

33 See, Bosphorus Airways v Ireland, judgment, 30/06/2005, no. 45036/98, Ignaccolo Zenide v Romania, judgment, 25/01/2000., no. 31679/96, Iglesias Gil and AUI v Spain, judgment, 29/04/2003, no. 56673/00 and Bianchi $v$ Switzerland, judgment, 22/06/2006, no. 7548/04

34 Svlienko v Latvia, judgment, 09/10/2003, no. 48321/99

35 Sunday Times $v$ United Kingdom, judgment, 26/04/1979, no. 6538/74

36 Harris, O’Boyle, Warbrick, op. cit note 4, p. 344-345
} 
Non-compliance in this respect, from supervision to adoption, ultimately leads to the ECHR establishing violations of Article 8 on grounds that interference was not in accordance with the law, which would meet the criterion of legality.

As a general principle of human rights regulations, the requirement for lawfulness means the acceptance of the rule of law. The human rights regulation and the rule of law are therefore inseparable concepts. When it comes to the application of Article 8 , it cannot be observed only in the context of protection of fundamental human rights, but also in the sense that protection of human rights is in conformity with the rule of law. Hence, broad discretionary powers of decision-makers are contradictory to the rule of law. This means that decision-makers must not have unlimited power but make decisions according to existing laws. These laws must be in line with the human rights standards. The possibility of changing existing laws must not be too easy. Stable laws are also an aspect of the rule of law. ${ }^{37}$

\subsection{Legitimate Aim}

This criterion calls for the possibility of justification for interference by referring to acceptable grounds or legitimate aims and purposes for limiting the rights referred to in Article 8. The sued State must set the grounds for interference in accordance with the protection of individual rights. However, the grounds that justify state interference in the rights of individuals are broadly set. These legitimate restrictive targets include national security, the rule of law and security, protection of the rights and freedoms of others, prevention of disorder or crime, protection of health and morals, and economic well-being of the country. If such a legitimate limitation objective cannot be identified, the attempt of restriction will be unlawful. Therefore, if the restriction cannot be justified by reference to one or more of the five grounds set out in Article 8, paragraph 2,it cannot be considered to have a legitimate aim and will be considered a violation of Article 8 . All that is required at this stage is to examine the facts in order to ascertain whether the interference was legitimately aimed. The current practice of the ECHR ${ }^{38}$ shows that it most commonly accepts that the manner in which the state had acted has been directed towards a legitimate aim, because the grounds for legitimate interference are very wide. Once found that interference does indeed pursue a legitimate aim, a balance between competing interests is established. ${ }^{39}$

\footnotetext{
37 Interights, op. cit., note 9, p. 17-18

38 See for example, Moscow Branch of the Salvation Army v Russia, judgment, 05/10/2006, no. 72881/01, Barfod v Danske, judgment, 22/02/1989, no. 11508/85 and Observer and Guardian v United Kingdom, judgment, 26/11/1996, no. 13585/88

39 Interights, op. cit., note 9 , p. 23
} 


\subsection{Necessary in a democratic society}

The ECHR has found that it is not enough for the state to invoke some of the reasons to interfere with the rights of individuals and achieve the appropriate aim. It must prove that such interference was necessary in a democratic society. In the case Handyside $v$ The United Kingdom, ${ }^{40}$ the ECHR explained the concept of necessity as follows: "The ECHR notes ... that the term necessary ... is not synonymous with needful or acceptable, usually, useful, reasonable or desirable." It signifies an urgent social need to limit rights and that such need must be in line with the requirements of a democratic society. In the case Olsson $v$ Sweden ${ }^{41}$ the ECHR added that such urgent social need must be proportionate to the legitimate pursued aim. ${ }^{42}$

\subsection{Proportionality}

The proportionality of the request requires the existence of a reasonable relationship between the measures used and the aim pursued. Essentially, proportionality requires determining whether a measure aimed at promoting legitimate public policy and interfering with the rights under Article 8: 1.) is unacceptably broad in its application or 2.) imposes excessive or unreasonable burden on certain individuals. Factors that need to be taken into consideration when deciding whether an activity is disproportionate are: 1 . whether relevant and sufficient reasons substantiating it were outlined; 2 . whether there was a less restrictive measure; 3. whether there was a certain measure of fairness of the procedure during the decision-making process, 4 .) whether there were any protection measures against abuses, and 5.) whether the restriction eliminated the very essence of the right. Therefore, a decision made in the respect of the proportionality principle should undermine the right in question to the least possible extent. It should also be carefully formulated to meet the aims pursued and should not be arbitrary, unfair or based on irrational circumstances. ${ }^{43}$

The very fact that the measure itself is sufficient to achieve the intended purpose, such as the protection of public order, is not necessarily sufficient to satisfy the criterion of proportionality. In the context of Article 8, proportionality demands that the interference in the law is indeed necessary to protect national security and public order and that the accepted approach is a less restrictive method among

\footnotetext{
40 Handyside $v$ The United Kingdom, judgment, 07/12/1972, no. 5493/72

${ }_{41}$ Olsson v Sweden, judgment, 24/03/1988, no. 10465/83

42 Harris, O’Boyle, Warbrick, op. cit note 4, p. 349 et seq.

43 See, Golder v United Kingdom, judgment, 21/02/1975, no. 4451/70 and Hatton v United Kingdom, judgment, 08/07/2003
} 
those that could not achieve the desired effect. Diversity always requires the balance between the burdens placed on an individual whose rights are restricted and the interest of the public in achieving the objective that has to be protected. ${ }^{44}$

\subsection{THE RIGHT TO A HOME IN NORMS AND JUDGMENTS OF CROATIAN COURTS}

It can be argued that Article 8 of the Convention was not sufficiently recognised in domestic jurisprudence, or rather, that there has been lack of knowledge about the Convention and the content of its rights. Moreover, the doctrine states that, due to the traditional way of thinking, it has been inconceivable to deny the owner legal protection in terms of ownership in relation to the possessor - non-owner, unless there were objections that, for example, the possessor gained ownership of the real-estate in question. ${ }^{45}$ As the reception of ECHR practice does not have a long tradition, at the institutional level the conflict will have to be resolved primarily by the legislator and then by the courts.

\subsubsection{The Enforcement Act and the right to a home}

It seems that the legislator has not exercised its right, or rather failed to fulfil its obligation until the amendment of the Enforcement Act in $2017^{46}$ and did not prescribe that in the process of foreclosure the real estate that constitutes the only home of the debtor is to be considered an exempted property. Therefore, in 2017, primarily due to social reasons, the provisions of the Novel of the Enforcement Act sought to strengthen the legal position of the debtor in relation to the creditor. First of all, in 2017, the legal protection of a property considered to be a home was recognised in the enforcement procedure. Other major changes in the real estate enforcement procedure from the 2017 Novella of the Enforcement Act relates to: protection of the debtor who is a natural person (Article 75, paragraphs 5, 6, 7, and 8 ), special conditions for determining the enforcement procedure on realestate (Article 80 (b)), stay of enforcement procedure (Article 84 (a)), the position of debtor as a lessee (Article 127, paragraphs 2, 3, 4, and 5) and social housing of the foreclosed debtor (Article 131, 131b, and 131 (c))..$^{47}$ Naturally, a creditor

\footnotetext{
44 Interights, op. cit., note 9, p. 25-26

45 Kontrec, op. cit., note 3, p. 1061-1099

46 OG, no. 112/12, 25/13, 93/14, 55/16, 73/17

47 It should be pointed out that the mentioned issues are a part of broader problem matter. Namely, today most of EU Member States have satisfactory housing laws. In some, the right to housing is a constitutional category (exempli causa, Belgium, Slovenia, Spain, Greece, Portugal, and Sweden) or governed by appropriate laws (exempli causa, France, Denmark, Great Britain, and Germany). However, in all housing policies, it is common understanding that housing is not only understood as standard "roof
} 
who holds a valid enforcement title has the right to enforce his claim through the enforcement order. Returning to the topic at hand, the most important novelty is the fact that the EA for the first time determines what is to be considered the only home of the debtor and how it is protected in the enforcement proceedings. Thus, the only property of a civil debtor within the meaning of paragraph 5 of Article 75 of the EA is the one in which the debtor resides and that is necessary to satisfy the basic living needs of him and the persons he is legally obliged to support. Therefore, such property, as a place where the private and family life of the enforced person is conducted, is usually exempt from the enforcement procedure.

\subsubsection{The Consumer Bankruptcy Act and the right to a home}

Implementation of the Consumer Bankruptcy Act ${ }^{48}$ in the Croatian legal system introduced the possibility of conducting bankruptcy proceedings over the assets of all natural persons. Until this reform, the bankruptcy proceedings could only be carried out on the property of legal persons and the property of individual debtors according to the rules regulated by the Bankruptcy Act. ${ }^{49}$ Regarding the right to a home, the CBA states that after the initiation of court proceedings, the consumer may request by submitting a reasoned proposal to the court that, by the end of the conduct verification period, the real estate that he needs for housing, does not go on sale under the assumption that he has no other property in his ownership, other available accommodation, and that he is unable to obtain one. Upon such request, the court is obliged to invite privileged creditors to provide an opinion within a period of eight days about the consumer's proposal and to declare whether they give their consent. The court decides on the consumer's proposal within 15 days from the date of submission of the proposal or expiration of the deadline for the declaration of creditors who have secured right over the property, taking into account that the property must be proportionate to the basic housing needs of the consumer. Therefore, the court has discretionary power to decide not to sell the property until the end of the conduct verification period, after which it will assess

over the head", but as a civilization standard. The housing policy is a too complex issue, temporally and spatially, politically-economically, and institutionally too sensitive for the scope of this paper and would make it impossible to provide final or more specific answers to the raised questions. However, a part of the issue of adequate housing policy is also the issue that is in most countries governed by the laws on housing and maintenance of residential buildings. Thus, since one of the key problems posed by positive regulation is the insufficient or outdated legal framework that would regulate housing, the legislator should regulate this issue through the lex specialis Housing Act, which would also regulate the so-called "social housing"

48 OG, no. 100/15, hereinafter: CBA

49 The Bankruptcy Act, OG, no. 44/96, 29/99, 129/00, 123/03, 82/06, 116/10, 25/12, 133/12, 45/13. and the new Bankruptcy Act, OG, no. 71/15 and 104/17, hereinafter: BA 
the appropriateness of selling the property, taking into account the scope of settlement of all creditors who will settle from the property sale price. Creditors and consumers can appeal against the decision on sale within three days of delivery. In any case, if the sale of the property is assessed by the court as appropriate, it will ex offo initiate the enforcement procedure in order to collect a monetary claim and order enforcement of the consumer's home. ${ }^{50}$ Property sale is carried out by FINA, whose jurisdiction is determined by Art. 132 a of the EA according to which the request for sale and other documents in the process of property sale are submitted to the regional centres of the Agency, whose local jurisdiction is determined according to the jurisdiction of the enforcement court, i.e. the court in the area of which the real estate is located. In the said enforcement procedure, a trustee participates with the powers of the creditors, the sale costs are settled from the paid purchase, and the creditors settle according to the rules on settling the bankruptcy creditors (Article 64 of the CBA)..$^{51}$

\subsubsection{The realisation of the concept of right to a home in the practice of Croatian courts}

Regarding the above-mentioned regulations, it should be pointed out that until the completion of this paper there has been insufficient practical experience and judicial procedures to analyse the aforementioned novelties from a critical point of view. Nevertheless, we consider that the application of the above-mentioned provisions in the analysed segment should achieve a fair balance between competitive interests of the debtor and the creditor in the case of enforcement on the only property of the debtor or in situations where an insolvent consumer can potentially lose his home, and this situation, due to its psychological, social and economic sensitivity, also includes appropriate actions and court measures. Thus, it is indisputable that judicature will greatly contribute to the shaping of new insights into the "right to a home" institute. ${ }^{52}$

\subsubsection{The concept of home}

The current viewpoint of the Supreme Court of the Republic of Croatia is that a filed lawsuit with a vindication claim in civil proceedings, in the situation where

\footnotetext{
50 See, Mihelčić, G. in collaboration with Kontrec, D. Komentar Ovršnog zakona s opsežnom sudskom praksom i abecednim kazalom pojmova, Organizator, Zagreb, 2015, p. 350-500

51 See Bodul, D., Grbić, S., Kratka prolegomena „o pravu na dom“ u Zakonu o stečaju potrošača, Revija za socijalnu politiku, vol. 25, 2017, br. 2., pp. 169-189

52 See, Kunštek, E., O pravu na dom - recentna događanja, Novela Ovršnog zakona - 2017, Inženjerski biro, 2017, p. 162-172
} 
the defendant complains referring to the "right to a home", the concept of "home" should be a matter of fact for the court in which it decides according to the criterion of durability and factual connection, taking into account the circumstances of the particular case and legal considerations contained in the decisions of the Constitutional Court and the ECHR..$^{53}$ Moreover, the violation of the right to a home, in the event of forced eviction of the debtor and his family, is the most common constitutional right whose violation stands out in the constitutional complaints lodged with the Constitutional Court of the Republic of Croatia. Practice analysis shows that the views of the court's decisions are in line with ECHR standards. ${ }^{54}$

\subsubsection{Time to file a complaint and its content}

However, the "right to a home" is not an absolute and unquestionable right, since it must meet certain substantive legal and procedural legal criteria. Thus, it is on the debtor to prove that the disputed decision concerns his "right to a home", i.e. that there has been interference with his "right to a home ". In this regard, the Supreme Court of the Republic of Croatia states that the debtor - possessor, has the right to file a complaint based on the "right to a home" until the conclusion of the main hearing before the first instance court ${ }^{55}$ (Article 352, paragraphs 1 and 2 of the Civil Procedure Act). ${ }^{56}$ The Constitutional Court notes that the courts are obliged to examine these allegations although the party in question has not

53 Conclusions of the Supreme Court of the Republic of Croatia from the meeting of the President of the Civil Department of the Supreme Court of the Republic of Croatia with the Presidents of the Civic Courts of the County Courts, held on 16 and 17/09/2015, no: Su-IV-246/15, Conclusion no. 1. (Objection to the right to a home in civil proceedings concerning Art. 8 of the European Convention)

54 Decision no. U-III-46/07 of 22/12/2010, OG, no. 12/11; U-III-405/08 of 21/02/2012, OG, no. 38/12; U-III-2073/10 of 04/03/2014, OG, no. 41/14. Available on the website: [www.usud.hr] Accessed 12 January $/ 2018$

55 Conclusions of the Supreme Court of the Republic of Croatia from the meeting of the President of the Civil Department of the Supreme Court of the Republic of Croatia with the Presidents of the Civic Courts of the County Courts held on 11 and 12/04/2016, no: Su-IV-155/16, Conclusion no. 7 (highlighting the right to a home in litigation procedure)

56 OG, no. 53/91, 91/92, 58/93, 112/99, 88/01, 117/03, 88/05, 02/07, 84/0, 123/08, 57/11, 148/11, 25/13, 89/14. “...although the above-mentioned failure was made by the Šibenik County Court because the objection of interference with the applicant's right to a home was first raised in the appeal, the Constitutional Court also abolished the first instance verdict since that court, as the first instance court, is obliged to consider and determine all the facts and derive evidence for their determination, in order to start from the particular circumstances of the case, to assess those crucial for making a decision on the merits of the case. In other words, that court has the greatest knowledge of the facts of a particular case. Subsequently, based on the facts established in this manner, the Šibenik Municipal Court must examine the proportionality and necessity of the proposed measure with regard to the relevant principles that make up the content of the right to a home and are in accordance with the fundamental standards contained in the decision no: U-III-2073/2010 of 04.03.2014, Decision of the Constitutional Court of the Republic of Croatia, U-III/869/2014 of 29/08/2014 
explicitly stated the relevant constitutional or convention provision (Article 34 of the Constitution or Article 8 of the Convention), but this stems from its allegations which in itself constitute a reference to the right to a home (for example, staying in the apartment for many years, paying the rent regularly, constitutes an existential issue for the outcome of the litigation). ${ }^{57}$ The views of Croatian courts are also in line with the view of the ECHR that enforcement proceedings (which are by their nature extraordinary and whose primary purpose is to ensure effective enforcement of a judgment) is not, unlike ordinary civil proceedings, designed or appropriately equipped with procedural means and protection measures for thorough and contrastive examination of such complex legal issues.

\subsubsection{Implementation of the proportionality test and the viewpoints of the Supreme Court}

The courts are obliged to protect the convention rights of individuals and to implement the so-called "proportionality test" that provides the answer to the question does the order to evict an unauthorised user of the apartment constitute unjustified interference in his right to a home. It is implemented through three elimination questions - is the interference based on the law, is it aimed at achieving a "legitimate aim" and is it necessary in a democratic society? A negative answer to any of these questions means that the eviction is contrary to the Convention, i.e. unjustified. ${ }^{58}$ The power to implement the proportionality test is on the court conducting regular civil proceedings in which it has been decided on a civil claim demanding forced eviction. ${ }^{59}$ On the other hand, the burden of proof on whether the interference is directed at achieving a legitimate aim and whether forcible eviction is necessary in a democratic society is on the plaintiff.

57 Decision of the Constitutional Court of the Republic of Croatia, U-III/869/2014 of 29/08/2014. For example, the defendant's objection to the claim of the plaintiff who is property owner and who wants to evict the defendant, who claims he has nowhere to move because he has no other real estate and that, if the plaintiffs request were accepted, he would be thrown out on the street together with his children, who live with him in this home, in fact makes the content of a complaint concerning the right to a home. To be able to accept the plaintiff's request, the court must discuss and assess whether the property is home of the respondent and whether the interference is disproportionate or a necessary measure for achieving the legitimate aim (protection of the right of ownership) of the plaintiff

58 The Zagreb County Court,Gž-1423/16-2 of 10/05/2016; the Rijeka County Court, Gž-121/17-2 of 19/07/2017

59 Paulić v Croatia, judgment, 22/10/2009, no. 3572/06 


\subsubsection{Some Specificities}

It is important to point out that public legal entities (the state, local and regional government, legal entities owned by local and regional government) may appear on the side of creditors while on the side of debtors is always a natural personpossessor claiming that certain real-estate is his/her home. This becomes an issue considering the fact that in some cases the individuals occupy a residential area owned by public authorities. This defines the position of public authorities in such manner that "... the legitimate interest of the public authorities to control their property is ancillary compared to the tenants' right to their home. ${ }^{60}$

\section{INSTEAD OF A CONCLUSION}

We live in times of rapid social changes in all areas of human activity whose alleged purpose is to create better living conditions. In such circumstances, it is extremely important for legal science and practice to provide appropriate explanations on how to interpret and develop court practice. In a specific case, on the one hand, legal certainty requires that the law and the rights of third-parties are respected in the general and public interest. On the other hand, losing a home by foreclosure is not, nor will it ever be, just for the debtor, although enforcement procedure is in accordance with the law (it must be). It is therefore quite legitimate, and from a practical point of view justified and useful to analyse the practice of ECHR in the proceedings under Art. 8. The purpose of the paper was to gain insight into the legal and logical mechanism of decision-making of the ECHR by examining the legal institution of the right to a home, which is the result of the ECHR's long-standing practice, and to examine and analyse domestic judicature in order to gain insights into the problems domestic judiciary needs to "work on". For now, we can argue that domestic courts have started discussing, problematizing and implementing the concept of the right to a home only after they had started receiving ECHR decisions. The above-mentioned decisions required a review of domestic court practice, both in regular courts and the Constitutional Court of the Republic of Croatia, which is now in line with ECHR practice. Therefore, the accepted point of view is that the complaint of the right to a home is a matter of fact, in which in each case it should be determined whether there is a lasting and

60 The Constitutional Court of the Republic of Croatia, no. U-III-2073/10 of 04/03/2014. In this regard, see the practice of the Šibenik County Court: Gž 932/2015-2 of 13/02.2017/ Therefore, the First Instance Court correctly ruled that the plaintiff, as a legal person owned by the state, requesting the defendants to evict the apartment in question, violated their right to a home protected by Art. 8 of the Convention because the plaintiff failed to provide valid reasons for the reasonableness of the measure, i.e. that eviction of the debtor from the apartment would be justified by the necessary and legitimate interest of the plaintiff 
immediate connection between the debtor and the property he considers to be his home.

\section{REFERENCES}

\section{BOOKS AND ARTICLES}

1. Bodul, D., Grbić, S., Kratka prolegomena „o pravu na dom“ u Zakonu o stečaju potrošača, Revija za socijalnu politiku, vol. 25, 2017, No. 2., pp. 169-189

2. Harris, D. J., O’Boyle, M., Warbrick, C., Law of the European Convention on Human Rights, Oxford, Oxford University Press, 2009, p. 376

3. Interights, Pravo na poštovanje privatnog i obiteljskog života, doma i dopisivanja, Priručnik za izobrazbu odvjetnika/ica, p. 13-14

4. Kontrec, D., Pravo na dom u praksi Europskog suda i domaćih sudova, Pravo u gospodarstvu, Zagreb, vol. 56, 2017, no. 5, p. 1061-1099

5. Kunštek, E., O pravu na dom - recentna događanja, Novela Ovršnog zakona - 2017, Inženjerski biro, 2017, p. 162-172

6. Mihelčić, G. in collaboration with Kontrec, D. Komentar Ovršnog zakona s opsežnom sudskom praksom i abecednim kazalom pojmova, Organizator, Zagreb, 2015, p. 350-500

7. Omejec, J., Konvencija za zaštitu ljudskih prava i temeljnih sloboda u praksi Europskog suda za ljudska prava, strasburški acquis, Novi informator, Zagreb, 2013, p. 936

8. ECHR

9. Abdulaziz, Cabales and Balkandali v United Kingdom, judgment, 28/05/1985, no. 9214/80, 9473/81, 9474/81

10. Akdivar v Turkey, judgment, 16/09/1996, no. 21893/93

11. Barfod v Danske, judgment, 22/02/1989, no. $11508 / 85$

12. Barthold v Germany, judgment, 25/03/1985, no. 8734/79

13. Bianchi v Switzerland, judgment, 22/06/2006, no. 7548/04

14. Blečić v Croatia, judgment, 29/07/2004, no. 59532/00

15. Bosphorus Airways v Ireland, judgment, 30/06/2005, no. 45036/98

16. Buckley v United Kingdom, judgment, 25/09/1996, no. 20348/92

17. Demades v Turkey, judgment, 31/07/2003, no. 16219/90

18. Gillow v United Kingdom, judgment, 24/11/1986, no. 9063/80

19. Golder $v$ United Kingdom, judgment, 21/02/1975, no. 4451/70

20. Groppera Radio AG v Switzerland, judgment, 28/03/1990, no. 10890/84

21. Handyside $v$ United Kingdom, judgment, 07/12/1972, no. 5493/72

22. Hatton $v$ United Kingdom, judgment, 08/07/2003

23. Iglesias Gil and AUI v Spain, judgment, 29/04/2003, no. 56673/00

24. IgnaccoloZenide v Romania, judgment, 25/01/2000., no. 31679/96

25. Marckx $v$ Belgium, judgment, 13/06/1979, no. 6833/74 
26. McCann v United Kingdom, judgment, 13/05/2008, no. 19009/04

27. Moscow Branch of the Salvation Army v Russia, judgment, 05/10/2006, no. 72881/01.

28. Observer and Guardian v United Kingdom, judgment, 26/11/1996, no. 13585/88

29. Olsson $v$ Sweden, judgment, 24/03/1988, no. $10465 / 83$

30. Oluić v Croatia, judgment, 20/05/2010, no. 61260/08

31. Paulićv Croatia, judgment, 22/10/2009., no. 3572/06

32. Prkopovich v Russia, judgment, 18/11/2004, no. 58255/00

33. Rijeka County Court, Gž-121/17-2 of 19/04/2017

34. Stubbings et al. v United Kingdom, judgment, 22/10/1996, no. 22083/93, 22095/93

35. Sunday Times $v$ United Kingdom, judgment, 26/04/1979, no. 6538/74

36. Surugiu v Romania, judgment, 20/04/2004, no. 48995/99

37. Svlienko v Latvia, judgment, 09/10/2003, no. 48321/99

38. Wiggins $v$ United Kingdom, decision, 08/02/1978, no. 7456/76

\section{NATIONAL REGULATONS, ACTS AND COURT DECISIONS}

1. Conclusions of the Supreme Court of the Republic of Croatia from the meeting of the President of the Civil Department of the Supreme Court of the Republic of Croatia with the Presidents of the Civic Courts of the County Courts, held on 16 and 17/09/2015, no: $\mathrm{Su}-\mathrm{IV}-246 / 15$, Conclusion no. 1. (Objection to the right to a home in civil proceedings concerning Art. 8 of the European Convention)

2. Conclusions of the Supreme Court of the Republic of Croatia from the meeting of the President of the Civil Department of the Supreme Court of the Republic of Croatia with the Presidents of the Civic Courts of the County Courts held on 11 and 12/04/2016., no: $\mathrm{Su}-\mathrm{IV}-155 / 16$, Conclusion no. 7. (highlighting the right to a home in litigation procedure)

3. Constitutional Court of the Republic of Croatia, no. U-III-2073/10 of 04/03/2014

4. Constitutional Court of the Republic of Croatia, U-III/869/2014. of29/08/2014

5. Constitutional Court of the Republic of Croatia, U-III-405/08 of 21/02/2012

6. Constitutional Court of the Republic of Croatia, U-III-46/07 of 22/12/2010

7. Šibenik County Court, Gž 932/2015-2 of 13/02/2017

8. Zagreb County Court, Gž-1423/16-2 of 10/05/2016.

9. Enforcement Act, OG, no. 112/12, 25/13, 93/14, 55/16, 73/17

10. Bankruptcy Act, OG, no. 44/96, 29/99, 129/00, 123/03, 82/06, 116/10, 25/12, 133/12, $45 / 13$

11. Bankruptcy Act, OG, no. $71 / 15$ and $104 / 17$

12. Civil Procedure Act, OG, no. 53/91, 91/92, 58/93, 112/99, 88/01, 117/03, 88/05, 02/07, $84 / 0,123 / 08,57 / 11,148 / 11,25 / 13,89 / 14$

13. Consumer Bankruptcy Act, OG, no. 100/15 